\title{
Urban Spaces, Plants, and People in the Nineteenth-Century Bogotá, Colombia
}

\author{
Diego MolinA* (1) \\ Department of Humanities, Universidad Nacional de Colombia, Bogotá, Colombia \\ *Corresponding author; e-mail: damolinaf@unal.edu.co
}

\begin{abstract}
Urban Spaces, Plants, and People in the Nineteenth-Century Bogotá, Colombia. Despite recent efforts to understand the uses of plants in Latin American cities, we know little about ethnobotanical practices in the pre-industrial nineteenth-century urban environments of this region. In order to address this gap in the existing literature, I examined the uses of ornamental, edible, and medicinal plants alongside "non-timber forest products" (NTFPs) in daily life in Bogotá (Colombia) between 1830 and 1910. Primary and secondary data were collected from textual and iconographic historical sources in libraries, archives, museums, and herbaria in Colombia and the United Kingdom. The results suggest that access to urban spaces such as patios, solares, or adjacent ecosystems broadly defined the ways that people related to and used plants, which in turn illustrates how social hierarchies influenced botanical knowledge. This study represents an initial effort to explore the heretofore neglected history of ways of using plants in Latin American cities in the period immediately prior to their modernization.
\end{abstract}

Los espacios urbanos, las plantas y la gente en la Bogotá del siglo diecinueve. Los conocimientos y prácticas etnobotánicas presentes en las ciudades latinoamericanas previas a su industrialización es un tema pobremente tratado por académicos. En un intento por abordar este tema, este artículo examina los usos dados a las plantas ornamentales, comestibles y medicinales, así como a los productos no maderables del bosque en la cotidianidad de Bogotá entre 1830 y 1910. Esta investigación hace uso de fuentes histórica primarias y secundarias en forma de textos e imágenes presentes en bibliotecas, archivos históricos, museos y herbarios de Colombia y el Reino Unido. Los resultados obtenidos sugieren que los usos de las plantas en Bogotá estaban definidos por jerarquías sociales fuertemente establecidas que permitían, o no, el acceso de los ciudadanos a ciertos espacios como patios, solares o ecosistemas cercanos. Este estudio debe ser considerado como un esfuerzo inicial hacia el entendimiento de los usos botánicos en las ciudades pre-industriales de American Latina.

Key Words: Historical and urban ethnobotany, Urban spaces, Bogotá, Patios, Solares, Botanical wisdom, Nineteenth century.

\section{Introduction}

The Latin American city has produced particular arrangements of plants and specific urban botanical practices in every historical period. Archeological and historical evidence has highlighted the role of plants in urbanism among some pre-Columbian societies. For instance, it is widely known that

${ }^{1}$ Received 30 September 2020; accepted 23 June 2021; published online 26 October 2021 highly developed horticultural practices enabled the Aztecs to endow their cities with up to five different types of green spaces comprising ludic and botanical gardens, orchards, chinampas, and urban forest (Evans 2000; Morales 2004). Archaeobotanical investigations have also demonstrated that Mayan cities had a diverse array of gardens and parks whose elaborateness extended well beyond that of ordinary household horticultural spaces such as kitchen or home gardens (Caballero 1992; Stark 2014). However, the preColumbian gardening sophistications were not generalized throughout the continent. In places such as 
today's Colombia, horticultural developments were more discrete, entuned with the smaller dimensions and complexities of its urban settlements (Langebaek 1987).

The European conquest of the Latin America imposed new ways of conceiving and building the city as a spatial organization of the new ruling powers (Romero 2014). This European-like urban reality included varying types of green spaces and was accompanied by the introduction of edible, ornamental, and medicinal plants that were highly valued by the new social rulers and changed the floristic composition of human settlements in the Americas (Patiño 1967). Hence, the introduction and acclimation of plants as an integral part of European cities in the Americas was the urban expression of the well-studied Columbian biological exchange (Crosby 1993). The result of this biological exchange of species used in cities produced an integration of European plants into American botanical knowledge linked to medicine, food, and gardening (Aceituno and Martín 2017). However, regardless of the strong tradition of botanical studies emerged after colonial scientific enterprises such as the Royal Botanical Expedition to New Granada (1783-1816), it is not yet well understood to what extent the European urbanism imposed in Latin America engendered specific ethnobotanical practices as a consequence of the new green space implemented in the construction of the colonial city.

The nineteenth-century modernization of Latin American and their integration into the broader global trade system engendered a radical transformation of urban environments characterized by the creation of new green spaces such as parks and urban forests (Amigo 2018; Molina 2015). However, we have limited information about the uses of plants prior to the establishment of designed green public spaces and how the permanence of colonial green spaces still in use during the last decades of the nineteenth century helped to maintain certain urban ethnobotanical practices that would disappear with the modernization of the city.

This study aims to shed light on the uses of plants in nineteenth-century Latin American urban spaces in the decades leading to the region's industrialization and modernization. To accomplish this goal, this study examines the case of Bogotá (Colombia) between 1830 and 1910. During this period, a series of new social actors such as journalists and travelers produced a hitherto unseen description of the city and its progressive transformation from a colonial-like shape of domestic green spaces to a modern city of public parks and gardens. Thus, this research seeks to answer the following questions: i) What kinds of green spaces existed in the nineteenthcentury Bogotá prior to its urban modernization? ii) What plants were used in the construction of these spaces? and iii) What people were commonly in charge of or associated with these spaces and their plants? By answering these questions, this investigation contributes to expanding our limited understanding of the ethnobotanical practices that existed in Latin American cities prior to the massive transformation engendered by its modernization and industrialization.

\section{Material and Methods}

\section{Geographical and Historical Background}

Bogotá is a city located at $2,600 \mathrm{~m}$ in a highaltitude plateau named the Sabana de Bogotá (Bogotás plain). Its temperature and rainfall average of $13.5^{\circ} \mathrm{C}$ and $900 \mathrm{~mm}$, respectively. Likewise, Bogotá is immersed in a diverse web of ecosystems formed by wetlands, moorlands known as páramos, high and middle altitude cloud forest, flooding forest, and dry areas (Calvachi 2002). This ecosystemic mosaic confers the city with very high levels of biological richness and an exceptional concentration of endemic species, confirming the relevance of the Tropical Andes as one of the most important hotspots of biodiversity in the world (Myers et al. 2000).

Regarding the human presence in Bogotá, when the Spanish arrived in 1537 in Bogotás plain, they found a complex and organized society with more than 5,000 years of presence in the territory (Van der Hammen 2003). This long-term pre-Columbian settlement permitted the development of a sizeable botanical knowledge manifested in the diversity of vegetal products used and traded by Muiscas (as has been later recognized this pre-Columbian society) (Langebaek 1987). After taking the social power, the Europeans founded the city of Santafé de Bogotá and created a colonial government. The encounter between the native Americans and the Europeans produced large and complex processes of biological, cultural, and ethnical miscegenation, creating then a hybrid culture (Paz 1999), and therefore a hybrid way of understanding plants.

After the end of the Colonial period in 1819, the conflicts involved in the contrasting ideas around 
the creation of the nation-state led to a series of civil wars worsening the general impoverishment and social exclusion product of the conquest campaign (Samper 1898). During the transition toward the twentieth century, the country underwent an industrialization process and an urban modernization, which consequently produced massive transformations in the green spaces and changed the historical uses of plants in cities.

\section{Historical ETHNOBOTANY}

This study adopted a historical ethnobotanical approach. Defined as the use of historical methods to examine past interactions between humans and plants (Medeiros and Hanazaki 2009), this approach draws on information obtained from written and iconographic documents preserved in libraries, archives, museums, or herbariums (Silva et al. 2014). Written sources included official documents, newspapers and magazines, travelers' accounts, scientific publications, and other literature, whereas iconographic sources used to expand the information provided by written sources included art and photographs. The data were obtained from the "Archivo General de la Nación (AGN)," the Biblioteca Nacional, and the "Luis Ángel Arango Library" (BLAA) in Colombia as well as the Kew Botanical Gardens library and archives in the United Kingdom.

Rather than generate a complete list of the entire botanical universe present in nineteenthcentury Bogotá, this research highlights the overlooked but marked presence of plants and ethnobotanical knowledge in the daily life of this pre-modern city. However, by lacking physical evidence (e.g., voucher specimens), this study acknowledges and tries to deal with the complexities implied in endowing vernacular names with a binomial taxonomic identity (Bye and Linares 2015). Therefore, when historical evidence included scientific names, they were updated using the Plants List (http://www. theplantlist.org/). Otherwise, common names were matched with scientific names that were the most plausible hypothesis after a process of triangulation with contemporary and historical sources in a method that included the following.

a) The use of digital tools such as Tropicos (https:// www.tropicos.org/home), JSTOR Global Plants (https://plants.jstor.org/), and Biodiversity
Heritage Library (https://www . biodiversitylibrary.org/) to explore nineteenthcentury botanical collections and specialized publication (e.g., horticulture catalogs) capable to inform about the taxonomical identity of plants only known through their common name.

b) Contrasting the vernacular names with the entrances of the Common Names of Plants in Colombia platform, whose database encompasses information from more than 200 published sources and specimens from seven herbaria (http://www.biovirtual.unal.edu.co/ nombrescomunes/en/).

c) Use of the Catalog of Colombian Plants and Lichens (http://catalogoplantasdecolombia.unal. edu.co/en/), which was helpful to confirm binomial names based on biological distribution, collection locations, and reported uses. Importantly, having sources written in Spanish, French, and English, the matching between common and binomial names was made using the original name as presented in the historical source without any translation (Mead 1970).

d) Despite these efforts, when a common name referred to two or more species, all candidates were presented.

e) Finally, when it was not possible to provide a clear taxonomic identification, they were not considered within the results (Electronic Supplementary Material [ESM] Appendix 1).

\section{Results}

This section presents a typology of the common green spaces in pre-industrial Bogotá stressing the plant species and the people that could be found in them.

\section{Ornamental Plants in Patios}

The colonial and early republican Latin American cities did not have plants on their streets or squares (Fig. 1). Instead, the presence of plants in the city's built environment was circumscribed in domestic spaces. For instance, ornamental plants in the pre-industrial Bogotá were mainly related to private spaces of upper-class houses. Known as casas de patios (houses with patios), they were the Latin American expression of ancient 


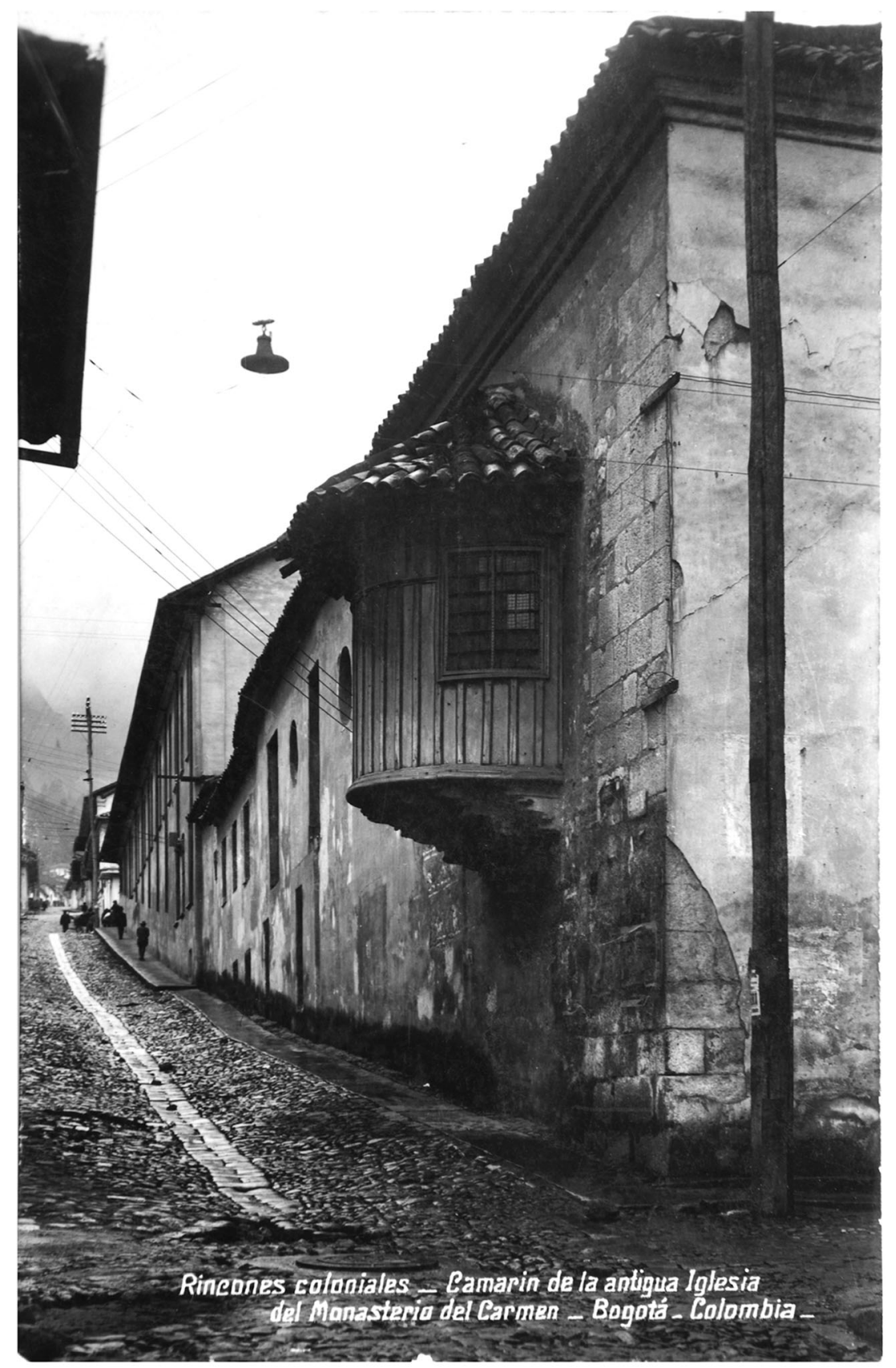

Fig. 1. Typical colonial street in Bogotá, ca. 1910 (Biblioteca Pública Piloto, Medellín)

houses with inner courts historically built in Spain (Capitel 2005). The data suggest how some of these spaces were commonly adapted as interior gardens
(Fig. 2). Soledad Acosta de Samper, considered the most important nineteenth-century Colombian woman writer, left a piece of extremely rare evidence 


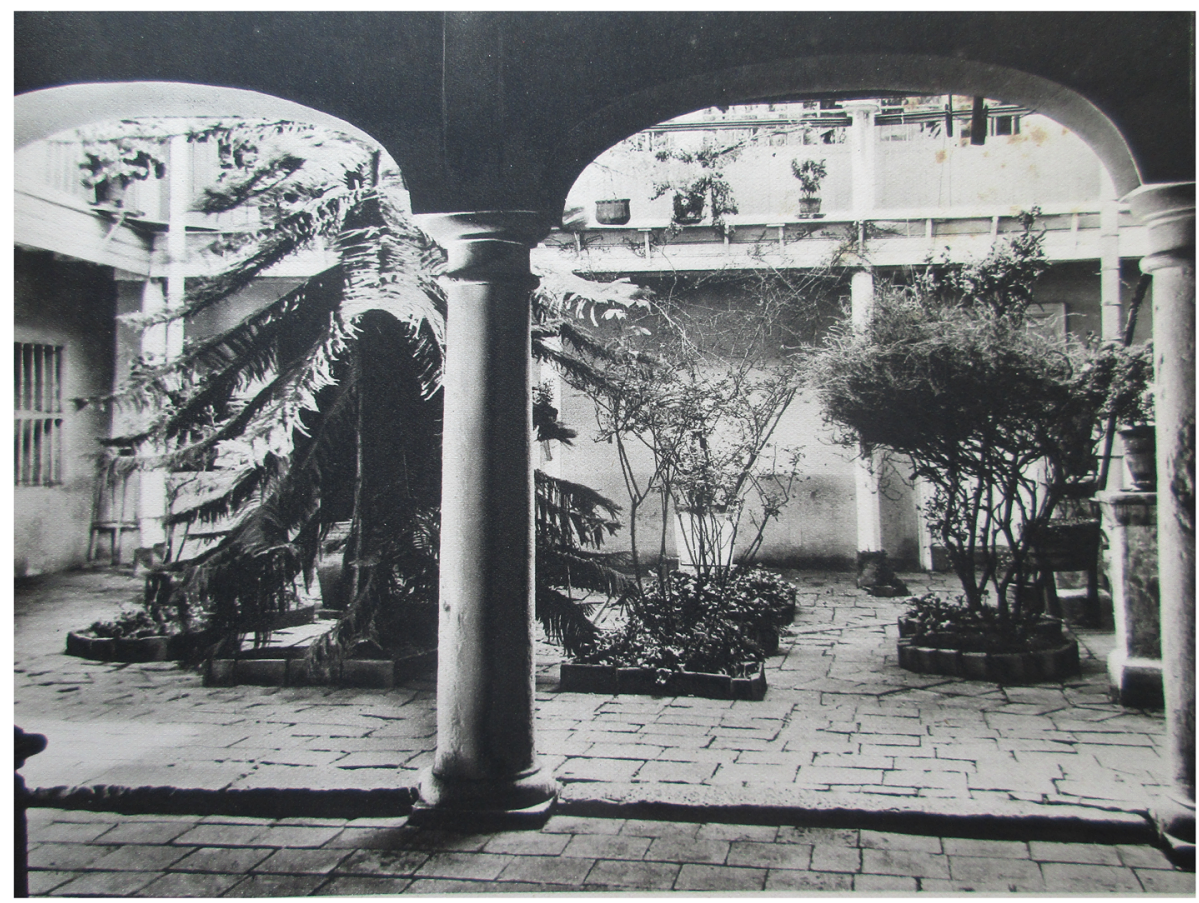

Fig. 2. Private house patio, ca. 1920 (Sociedad de Mejoras y Ornato, Bogotá, 1938)

concerning the domestic use of plants in Bogotás patios before the modernization process. In her 1870 book Mi Madrina (My Godmother), Acosta described the early nineteenth-century patio of a Bogota's colonial house thusly:

"I still remember that place as it was before. I can see the tall "romero" (Rosmarinus officinalis L.) always in blossom, the "tómate quiteño" (Solanum betaceum Cav.), "ciruelo" (Prunus domestica L.) and the "retamo" (Genista monspessulana (L.) L.A.S.Johnson) surrounded by "malvarosas" (Alcea rosea L.) growing in between the loose rocks, alongside many "rosales de alameda y de Jericó" (Rosa gallica L.) in whose shadow grew a fluffy carpet made out of "manzanillas" (Matricaria chamomilla L. / Chamaemelum nobile (L.) All.) and tinged "trinitarias" (Bougainvillea glabra Choisy) — replaced now by nonfragrant "pensamientos" (Viola tricolor L.) I also remember a strawberry plant (Fragaria vesca $L$.) whose leaves I always stopped to admire whenever I encountered the fruits. There were "novios" of open mound and pigeon feet classes (Pelargonium spp.). In the stone bench that separated the patio and the corridor there were bowls whose flowers were more carefully tended: they had blue and white "farolitos" (Campanula medium L.), yellow "ridiculos" (Calceolaria sp.), "botón de oro y de plata" (cf. Achyrocline satureioides (Lam.) DC.), "pajaritos" of all colors (Epidendrum cf. ibaguense Kunth). The columns were climbed by "donzenones" (Lathyrus odoratus L.) and "madreselvas"(Lonicera japonica Thunb.) And finally, on the floor by four molded clay pots-they were used to collect water during winter-you could find flowerpots and broken plates in which some seedlings grew waiting to be transplanted at the appropriated time. Almost all the flowers loved by my godmother back in the days have lost their importance, and only can be found in the old-fashioned gardens of those decadent Santafereños." 


\section{- Acosta de Samper [1870] 2013, pp. 17- 32.}

Despite the high botanical richness of the Andean region, the species used in the construction of domestic gardens in patios were mostly of European origin. The French horticulturist, landscape architect, and plant hunter Édouard-François André confirmed it when passing by Bogotá in 1875 wrote that patios were furnished with randomly placed ornamental plants such as "giroflée cocardea" (Matthiola incana [L.] R.Br.), fuchsias (Fucshia spp.), "pelargonium zonals" (Pelargonium zonale [L.] L'Hér. ex Aiton), "pelargonium a grandes fleurs" (Pelargonium cf. grandiflorum Willd.), "asperger" (Asparagus officinalis L.) —As ornaments!- "verveine citronnelle" (Aloysia citriodora Palau), "iris flambe" (Iris sp.), "giroflée des murailles" (Erysimum cheiri (L.) Crantz), "pavots" (Papaver spp.), "œillets de poète" (Dianthus barbatus L.), "œillets de fleuriste" (Dianthus caryophyllus L.), "dauphinelle bleues" (Delphinium elatum L.), "lupin” (Lupinus sp. / Lablab purpureus [L.] Sweet), "fusains du Japon" (Euonymus japonicus Thunb.), "soucis" (Calendula officinalis L.), "callas d'Ethiopie" (Zantedeschia aethiopica [L.] Spreng.), violette (Viola odorata L.), and "primevères de Chine" (Primula sp.) always flowered.” Although André highlighted the presence of native plants such as the "neyel de Colombie" (Juglans neotropica Diels) in the center of some patios, he observed how "Everywhere is evident the efforts in choosing the flowers brought from Europe" (André 1878), thus evidencing the strong influence of European flora in the domestic spaces of Bogotá.

The overwhelming presence of introduced ornamental plants seems to downplay the knowledge of native species with ornamental potential. In 1899 , José María Cordovez, a nineteenth-century Colombian chronicler, remembering the types of flowers used in Bogotá during the first half of the century, observed "regarding flowering plants, it is necessary to confess it, the number known by them (Bogotanians) was reduced. By that time, there was no notion about the immense richness and variety of the Colombian flora." He specifically highlighted how few species of flowering plants such as "rosas de castilla" (Rosa gallica), "claveles sencillos" (Dianthus caryophyllus) and "clavellinas" (Dianthus barbatus), "amapolas" (Papaver spp.), "espuelas de galán sencillo" (Tropaeolum majus L. I Consolida ajacis [L.] Schur), "pajaritos"
(Epidendrum ibaguense), "varitas de San José" (Guadalupe parasites [local undetermined orchids]), and "azucenas blancas" (Lilium candidum L.) were the main material from which the flower decorations were made by those days" (Cordovez 1899).

Differing from the labor class women such as washerwoman, whose job involved a constant transit along streets, elite women's transit around the city was limited and only socially accepted when it was related to activities such as support of philanthropic causes. Accordingly, the domestic space in pre-industrial Bogotá was eminently related to women (Martínez 1996). One of the main domestic activities carried out by women of high society was the creation and management of gardens in patios (Reyes and González 1996). There, the house's mistress unfolded a particular esthetic approach to plants based on vernacular horticultural knowledge and practices. One of the main characteristics of these gardens planted by women in patios was their portability. Ornamental plants in patios were usually planted in both broken kitchen pots or brand new flowering pots bought to be used in the patios ornamentation (Acevedo 1869; Acosta de Samper [1870] 2013). Therefore, the reduced mobility of women in the colonial society of Bogotá paradoxically produced a particular kind of mobile garden characterized by easily transported plants planted in pots that could be interspersed with the more fixed planting spaces (see the upper part of Fig. 2).

\section{Edible and Medicinal Plants in Solares}

The differentiation between the urban and rural realm in nineteenth-century Bogotá was not clearly sketched. One of the most significant characteristics of this lack of physical differentiation was the large presence of agriculture practices within the city. An example of this rural-urban interwoven reality was expressed in the use of growing plants in solares. The term solar was used to designate the part of the plot that remained following a house's construction. Often flanked with wide walls of rammed earth (tapia), the solar was a kind of backyard, or more accurately, it was a sort of condensed rural environment used to supply domestic requirements in terms of food, storage, and animal keeping. Although Bogotá was surrounded by arable land, the solar persisted as the most immediate productive and multifunctional piece of land (Fig. 3).

In contrast to patios, which were places devoted to contemplation through the esthetic organization of ornamental plants, the solares were dedicated to 


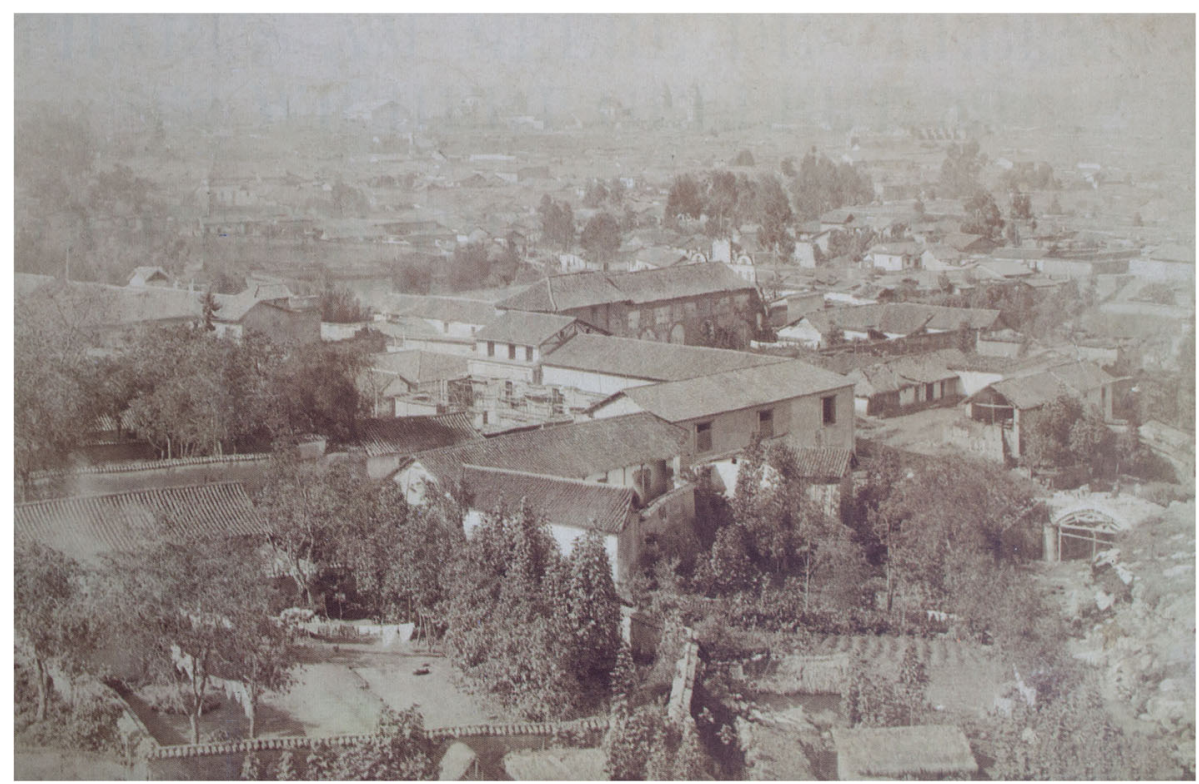

Fig. 3. Houses with solares, 1890 (Fundación Amigos de Bogotá, Antigua Bogotá 1880-1948, 2010)

the cultivation of edible and medicinal plants. Solares were versatile spaces used simultaneously as medicinal herb gardens, kitchen gardens, and orchards. Considering the medicinal herbs, Felipe Pérez, a prominent Colombian geographer, observed that they were "abundant in any vegetable garden" (Pérez 1862). Although the lack of historical evidence about the type of plants and their therapeutic uses in pre-industrial Bogotá, it could be stated that their cultivation in solares was as part of a vernacular pharmacopeia in the initial hometreatments of less serious ailments, such as diarrhea, fever, stomachaches, or the flu.

The second group of plants growing in solares was edible plants used to feed the culinary needs of the generally adjacent kitchen of firewood ovens. In 1852 during his pass in Bogotá, the Scottish botanist Isaac Holton observed that in the house of a Don Fulano (Mr. Nobody), there was a "second unpaved patio" with "a fig-tree" (Ficus carica L.), a "papaya" (Vasconcellea pubescens A.DC.), plums (Prunus domestica), and a minute apple-tree (Malus domestica Borkh. I Malus pumila Mill.) half dead with cold" (Holton 1857). Likewise, Felipe Pérez mentioned how in the city it was also possible to find some other cultivated fruit trees, such as "duraznos" (Prunus persica (L.) Batsch) and "cerezas" (Prunus serotina Ehrh.), growing along other spontaneous fruits plants such as "uva camarona"
(Macleania rupestris [Kunth] A.C.Sm. / Gaultheria sclerophylla Cuatrec.), "uva de anís" (Cavendishia bracteata [Ruiz \& Pav. ex J.St.Hil.] Hoerold), "mortińos" (Hesperomeles goudotiana (Ducq.) / Miconia sp. / Ericaceae spp.), "moras" (Rubus spp.), "esmeralda" (Miconia albicans [Sw.] Steud.), and "uchuvas" (Physalis peruviana L.) (Pérez 1862).

Some other vegetables and fruits cultivated in the solares according to Isaac Holton included, potatoes (Solanum tuberosum L.), and esculents such as "arracachas" (Arracacia xanthorrhiza Bancr), "cubios" (Tropaeolum tuberosum Ruiz \& Pav.), and "ocas" (Oxalis tuberosa Molina.), spinach (Spinacia oleracea L.), "curuba" (Passiflora tripartita [Juss.] Poir.), anise (Pimpinella anisum L.), "arverja" (Pisum sativum L.), fava beans (Vicia faba L.) and other beans (Phaseolus sp.), "maiz" (Zea mays L.), "pepinos" (Cucumis sativus L.), and pumpkins (Cucurbita máxima Duchesne) (Holton 1857). Finally, Soledad Acosta observed the presence of "chisguas" (Canna indica L.). The corms of this plant can be used to extract flour that traditionally has been used in the production of bakery products.

Thus, while the patios were spaces of esthetic contemplation created by the house's mistress, the solar was a place of production, closely related to the kitchen and body functions mainly administrated and cared for by women servants. In the solares, these women planted and cared for edible plants, 
medicinal herbs, and fruits tree devoted to the nurturing and healing needs of the family (Martínez 1996). Therefore, although poorly understood thus far, some women in pre-industrial Bogotá had a clear ethnobotanical and culinary knowledge that enabled them to cultivate within the city certain types of fruits, vegetables, and grains on the one hand, and additionally transform them into a diverse number of dishes characterized by the hybrid culinary heritage between indigenous and European cultures (Cook and Crang 1996).

\section{Plants from Nearby Ecosystems INCORPORATED INTO THE CITY}

The functioning of urban reality entails a constant physical and symbolic expansion beyond its built environment orders (Cronon 1992). Accordingly, plants from nearby ecosystems were systematically introduced into nineteenth-century Bogotá as raw-material, playing a prominent role in the city's daily life.

\section{Plants Used in Construction}

To create a Spanish-like city, the conquerors had to use what was at hand. This meant employing a native workforce: people embodying vernacular building practices, which included a knowledge-set of the natural resources involved in construction. Consequently, although the colonial city was eminently a European project, the truth is that it had to be developed using local people's building knowledge, which mostly involved a deep botanical knowledge of plants used as construction raw material.

Beyond the evident use of timber, colonial building construction demanded significant amounts of other types of vegetal raw-materials. The bamboolike "chusque" (Chusquea scandens Kunth) and the "pajonal" (Calamagrostis effusa [Kunth] Steud.), common in Bogotás surroundings, played key roles in the construction process (Figs. 4 and 5). From the latter, the Muiscas produced a highly resistant braid known as cuan (Spanish translation of the muisca word pquamne that literally means cord of straw) (http://muysca.cubun.org/MU/cuan) used to join chusque rods and in doing so, roof both natives' and conquerors' houses (Fig. 6).

Although economic constraints imposed severe limitations for the urbanization process, due to their physical resistance and the durability, the "chusque- cuan" couple was used each time a new house or public building was built (Fig. 7). Thus, the transplantation of the colonial house originating in Spain, which was inhabited mainly by Spanish or Spanish descendants (known as criollos), was made possible thanks to the accumulated botanical and architectonical knowledge used in the construction of indigenous people's spaces. The outstanding physical characteristics of "chusque-cuan" roofs also enabled this building technique to be integrated into the city's material transformation under modernization, as evidenced by the presence of cuan and "chusque" in a construction list published in the Anales de Ingenieria in 1887. The list shows that among many other construction raw materials, such as timber or nails, "chusque" was sold in parcels of 25 pairs, and a package of 25 pairs of cuan fiber was sold for 25 pesos (Lombana and Ayala 1887). Likewise, some years later, in 1906, when the government planned to build a new armory inside the San Agustin Monastery, the chief engineer requested 880 packages of "chusque" and the same quantity of cuan. Each of those packages was composed of 25 pairs of "chusque" sticks and 25 caun braids; thus, the overall number of those two vegetal products required for the armory construction was around 20,000 . This figure suggests a steady high level of exploitation of "chusque" and "pajonal," therefore implying an intensive alteration of their natural populations, which likely affected the páramo and cloud-forest ecosystems where "chusque" and "pajonal" respectively develop (Archivo General de la Nación [AGN]).

\section{Other Uses of Plants from Nearby Ecosystems}

Nineteenth-century Bogotá was a city considerably influenced by its traditions. Its cultural practices still reflected the "ritual atmosphere" that came with the medieval ideas implanted by Spaniards during the conquest (Romero 2014). Contrary to many other countries, industrial development proceeded slowly in Colombia and on a rather small scale. Although it had increased since independence in 1819 , trade developed slowly due to precarious infrastructural conditions worsening the city's historical isolation. Under these circumstances, most of the material elements consumed by people in Bogotá were extracted or produced locally and regionally using non-timber forest products (NTFPs) as raw-materials. Therefore, these plants, or products deriving from them, were used in a large range 


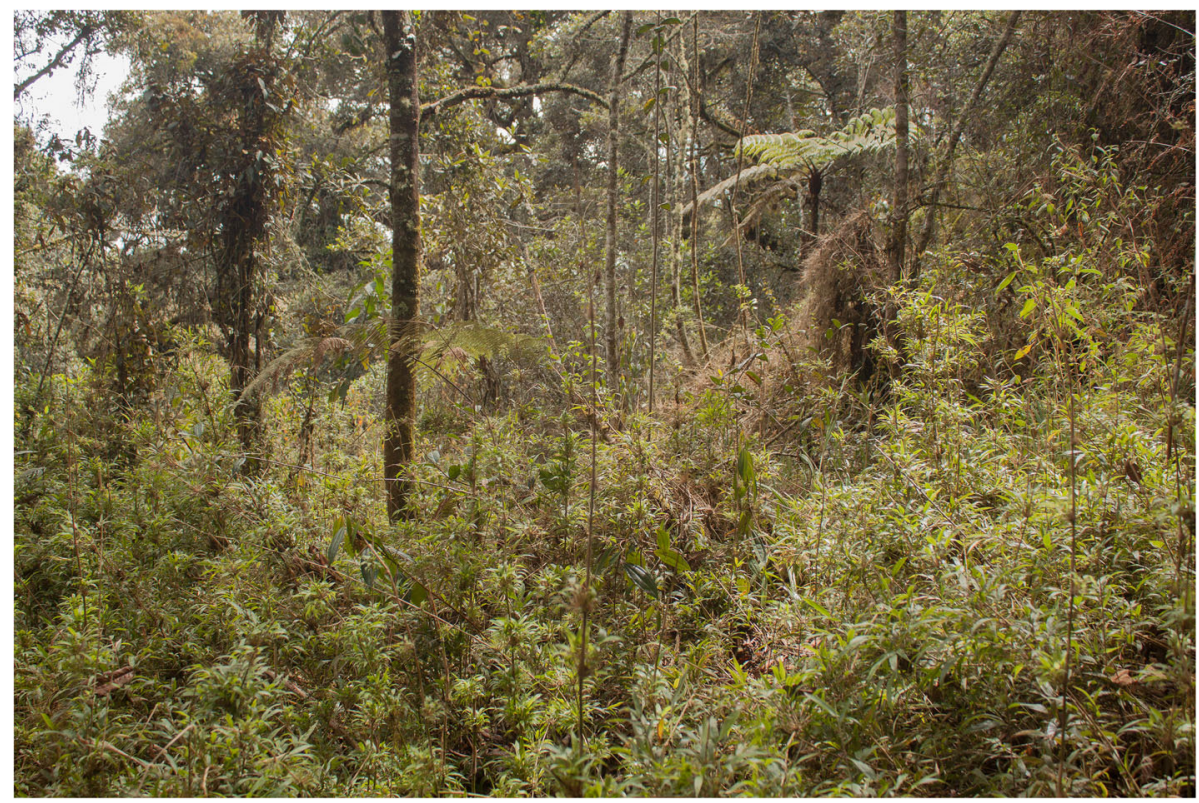

Fig. 4. Cloud forest understory dominated by Chusquea scandens close to Bogotá (Author’s image)

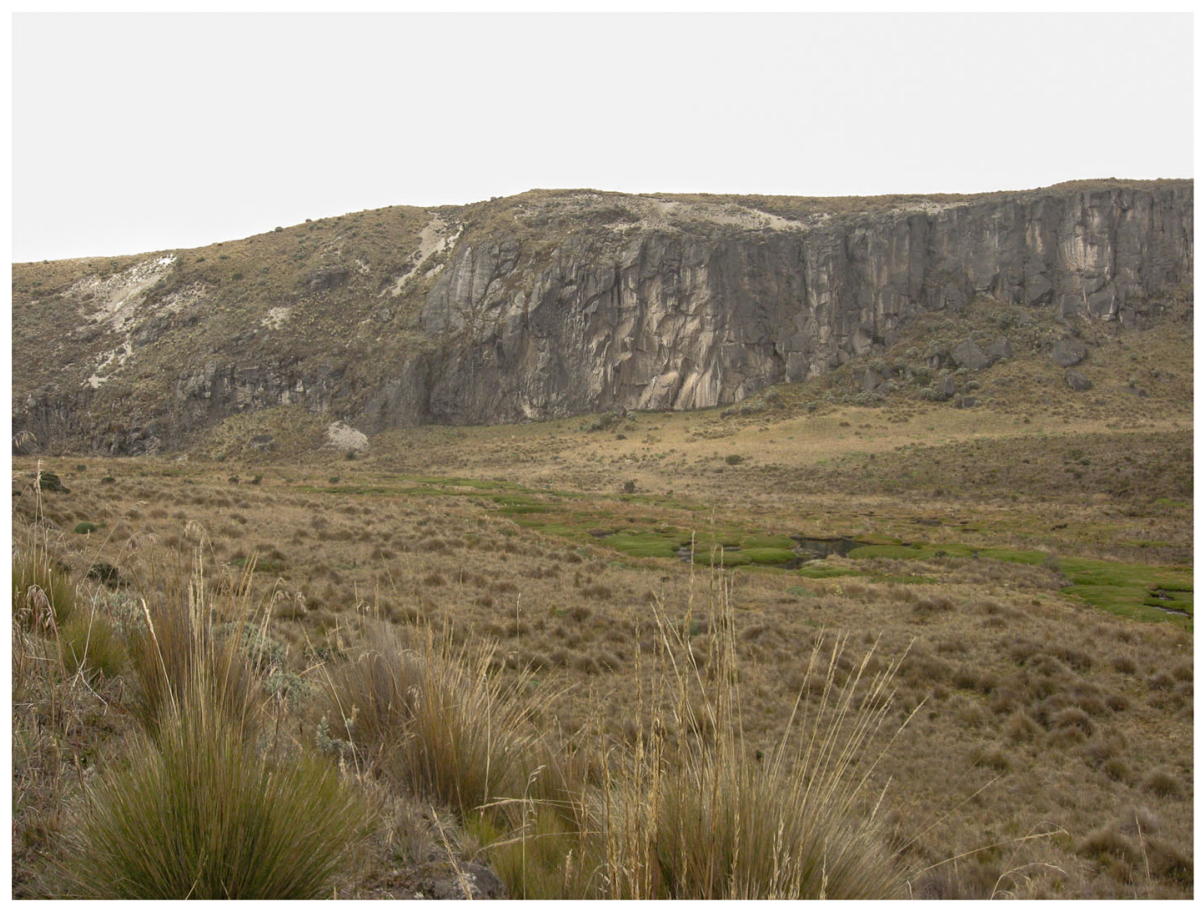

Fig. 5. Páramo ecosystem dominated by Calamagrostis effusa close to Bogotá (Author's image) 


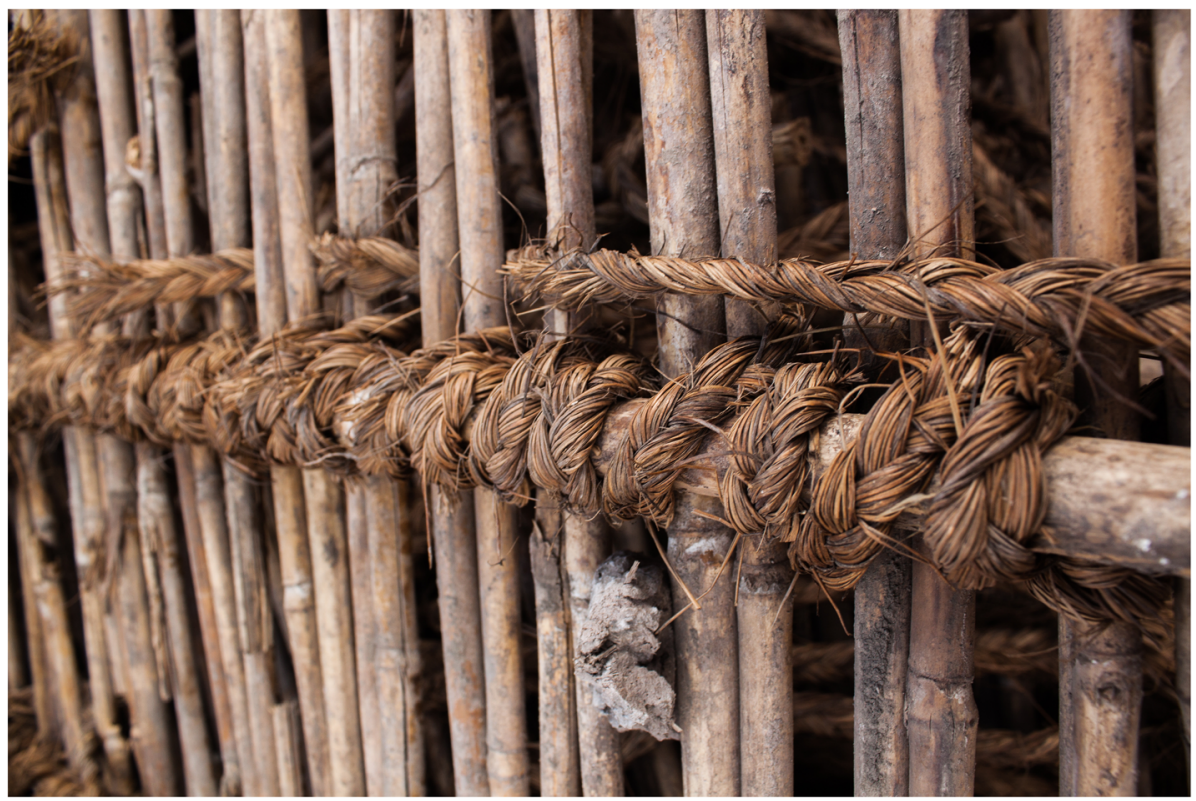

Fig. 6. Chusque and pajonal cord (cuan) (Author's image)

of activities. In 1888, a journalist pointed out this situation as shown below.

"Many years will pass, centuries perhaps before cultivated Europe gains sufficient knowledge about the richness, variety and luxury of the
Colombian plants. Was right the person who declared to have been found in the vegetal realm almost everything produced by humans around the world. Plants of nails, wire, and springs; of wires, cords, and cables, of vessels. Strong cups

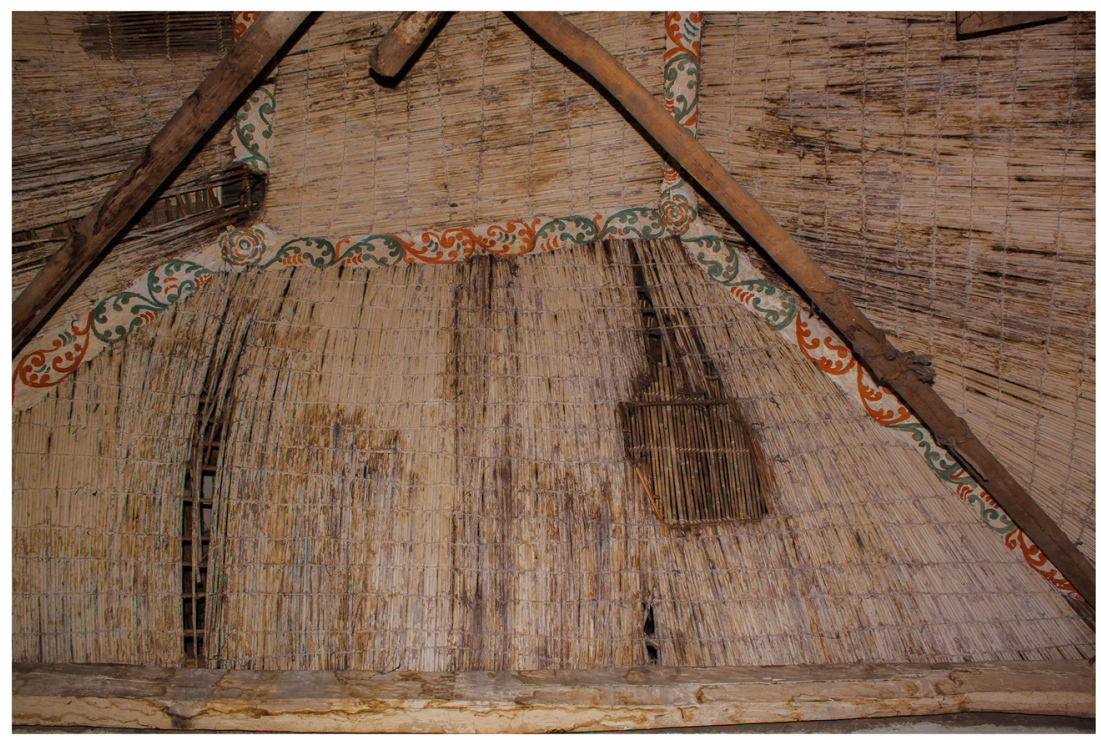

Fig. 7. Cuan net as part of the roof in a sixteenth-century house (Author's image) 
and spoons, [plants] of all diameter tubes, of candles, of liquors, of tills, and know not what more else, produced by our generous nature to make bearable the isolation in which we live; and to compensate in part the difficulties that do not allow us to be in contact with the large centers of civilization."

-Guerra 1888

Colombia's high biodiversity, relative geographic isolation, and underdeveloped national industry presupposed the prevalence of the use and exploitation of products coming from the wild. Bogotanians of the pre-modern city slept on mats made of "totora" (Schoenoplectus californicus [C.A.Mey.] Soják), a semi-aquatic plant that is abundant in the Tota lagoon $(240 \mathrm{~km}$ away from the city, Fig. 8). Also used as carpets, these vegetal mats were extensively used to provide adequate isolation against the chilly weather of a city located at 2,600 $\mathrm{m}$ in the Andean mountains (Cordovez 1899). Plants were also used to produce garments. For instance, the so-called sombrero de Panamá (Panamá hat), a highly esteemed piece of handcraft commonly worn by men, was made through the use of a vegetal fiber obtained from "iraca" (Carludovica palmata Ruiz \& Pav.), a middle elevation plant collected on the steep sides of Andean mountains. Similarly, people used the fruit of a gourd-like Asian plant called "estropajo" (Luffa cylindrica [L.] M.Roem.) as a sponge to clean bodies and dishes. Mops and brooms were also made through the use of plants. Likewise, hollow sticks coming from Chusquea scandens and other Andean bamboos, were used as tubes for water collection from public fountains in a city that long ignored the existence of hoses. Plants from nearby ecosystems were also

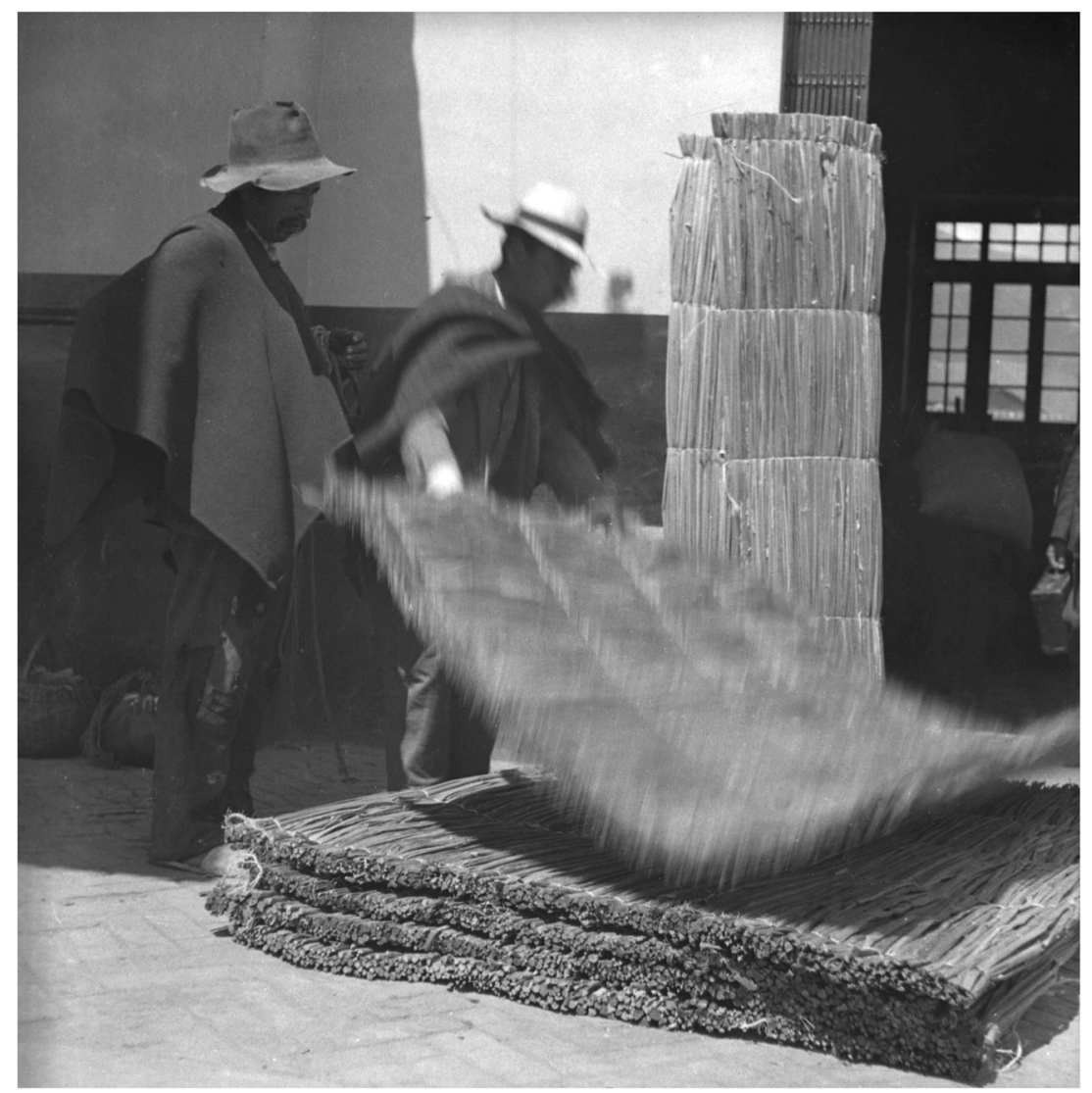

Fig. 8. Mats made of Schoenoplectus californicus from the nearby Tota lagoon, ca. 1930 (Collección Fotográfica Gumercindo Cuellar, BLAA) 
broadly used as kitchen utensils. Considering that the first pottery factory was not opened in Bogotá until 1833, and that there was not a single cutlery factory in Colombia during the first decades of the nineteenth century (Martínez 1996), the simplest kitchen tools were derived from plants. Perhaps the most remarkable example is the use of "totumos" (Crescentia cujete L.), a lowland plant producing thick and durable fruit, that was used in the production of spoons, plates, bottles, and cups. The traveler James Steuart described the extensive use of "totumos" as cups and glasses: "The coffee and the chocolate are not drunk with their meat, but immediately afterward, and then the same small cup is made use as in the morning. The disgusting habit of a whole family using one red earthen goblet or a totuma in common for drinking from is universal prevalent!” (Steuart 1838).

Whereas "totumos" were used to transport small quantities of liquid, woven baskets were primarily implemented for carrying various kinds of solid products. Much like modern plastic bags, woven baskets made of fibers or vine shoots were broadly used by the Bogotanians. However, the most important role was probably in the market. Baskets were used as containers in which people from the countryside brought their merchandise to be sold at the Friday market in the main city square (André 1878). For instance, it was common to see people transporting hens or chickens in small fiber-made cages specially made for poultry (Fig. 9).

People in contact with wild plants in Bogotá were the poorest (Figs. 10 and 11). They had no access to places like patios decorated through the manipulation of ornamental plants, and only some of them were employed as servants, therefore having a constant interaction with plants cultivated in solares. Conversely, they occupied small, dark, and poorly ventilated rooms commonly called tiendas. The botanist Isaac Holton described one of these rooms as "The little room looks like a prison cell, only it has no grated window, nor loop-hole, nor-breathinghole, except the open door." (Holton 1857). Deprived of spaces decorated with plants or places to grow their own vegetables, the historical evidence suggests that some of the most marginalized members of the society used their traditional ethnobotanical knowledge as a way to generate income.

An example of this is the city's constant demand for firewood and coal supplied by the work of poor people. In the specific case of charcoal, they needed to walk long distances to find suitable tree(s), turn them into charcoal, and afterwards carry it down to the city to sell."

Eugenio Diaz Castro in his 1880 book Bruna la Carbonera (Bruna, the Charcoal-maker Woman), wrote:

"Toward the East, on the top of the Monserrate and Guadalupe mountains, there is a large extension of land covered by scrublands. From there, the charcoal and firewood sellers obtain their subsistence products that supply of fuel the city. The vegetation of those mountains, barren at first glance, diminishes gradually until the hills are covered by 'pajonales' (Calamagrostis effusa) and the 'frailejón' (Espeletia spp.). This is the end of the vegetal realm."

$$
\text { —Díaz (1880) } 1985
$$

Although part of a literary narrative, the extract presents the harsh conditions faced by those who were in charge of supplying plants and NTFPs to the city. Equally, the iconographic evidence confirms how most of this people were part of the poorest class, and also suggests how they maintained and transferred a sort of ethnobotanical knowledge that enabled them to know, for example, the perfect moment to pick the "estropajos" and "totumos" from the plants, what kinds of vines were suitable for the construction of baskets, select the trees suitable to obtain charcoal, or to understand the best moment to extract from the nearby forest certain elements, such as moss and straw. Despite its importance, this pre-industrial traditional botanical knowledge was fundamental for the functioning of the colonial and pre-industrial city, and has received no attention by scholars.

\section{Discussion}

\section{ETHNOBOtanical KNOWLEDGE as a Reflection of Social Structure}

Historical evidence indicates that people in nineteenth-century Bogotá developed particular ways of using plants depending on their access to specific urban spaces, which in turn was determined by their social position. Thus, botanical knowledge was socially delimited, reflecting the lack of mobility 


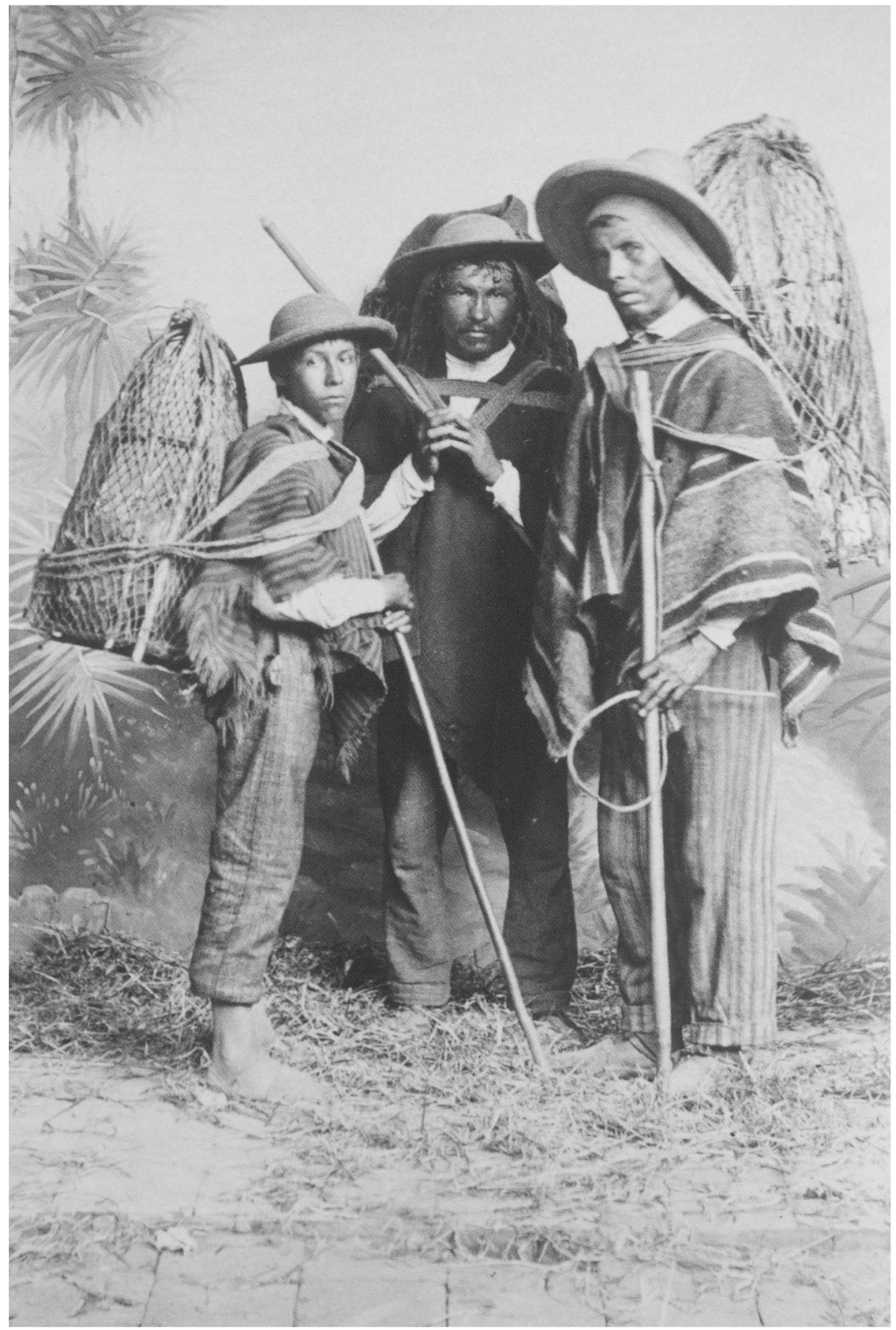

Fig. 9. Poultry sellers in Bogotá, 1848 (Dubail and Dubai-Acero 2017: Bourgarel, le Colombien)

in a highly hierarchical society such as that which existed in Bogotá throughout its history (Samper 1898; Zambrano 2007). Particular forms of botanical knowledge were possessed by certain groups and reproduced through generational transfer. This situation is exemplified through the 


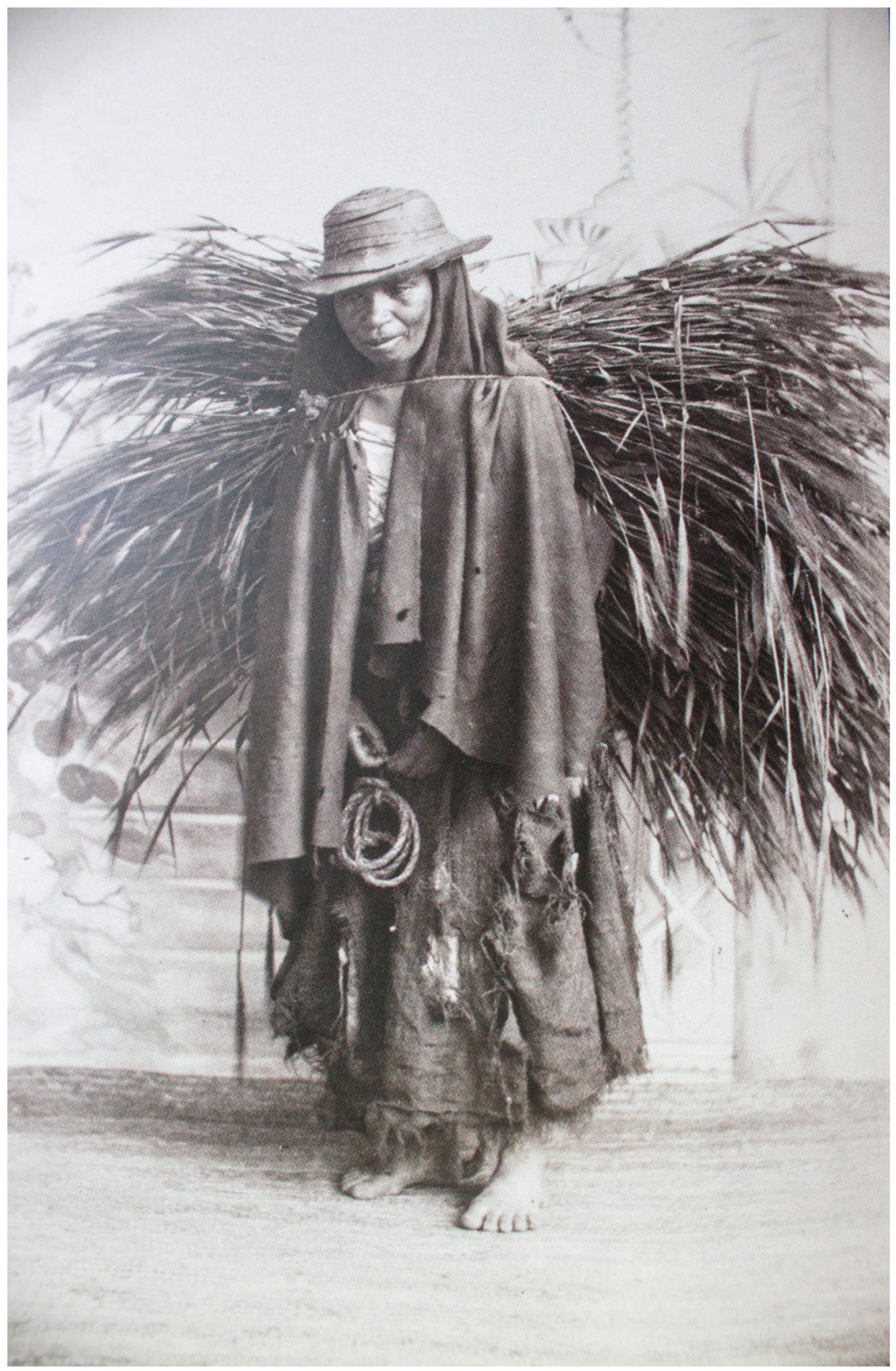

Fig. 10. Straw seller-woman in nineteenth-century Bogotá (Dubail and Dubai-Acero 2017: Bourgarel, le Colombien) 


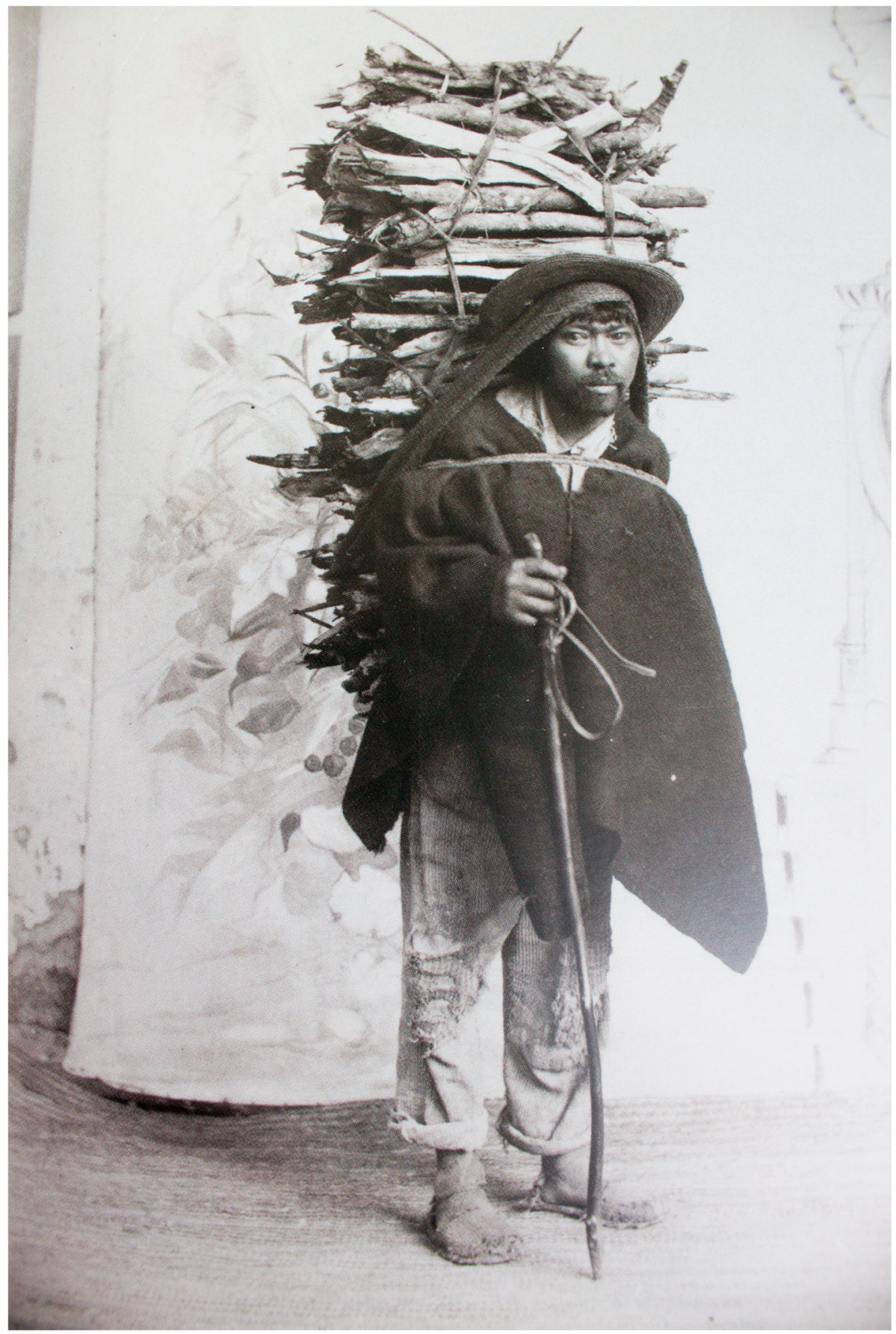

Fig. 11. Firewood seller in nineteenth-century Bogotá (Dubail and Dubai-Acero 2017: Bourgarel, le Colombien)

extended relationship between people and the ornamental plants cultivated in patios. A ubiquitous presence among patio decorations, carnations and roses were introduced to the Americas as early as 1520 with the migrations of Spanish women or entire families (Fernández de Oviedo y Valdés 
1526 1851). Like many other cultural elements, the European esthetic approach to plants would largely displace the symbolically rich botanical understanding that prevailed in pre-Columbian societies (Patiño 1967). Entrenched in the dominant culture, ornamental plants of European origin - which usually bore strong symbolic meanings (e.g., roses) —were rapidly adapted to urban spaces (Wylie 2018). Therefore, Europeans not only replicated the typical architecture of patios in houses in Spain (Silva 2001), they also attempted to reproduce the plants used to adorn these spaces in an effort to recreate their domestic landscape. The circulation and adaptation of European landscapes in patios demonstrates how human populations transport plants as an attempt to recreate their landscape and reproduce private and domestic settings (Anderson 1969; Crosby 1993). Thus, although further research is needed in this regard, the presence of ornamental plants that were highly valued in European culture in nineteenth-century patios, which were mostly inhabited by Spanish descendants, reflects the perpetuation of a botanical tradition that emerged within a specific social group-the Spanish colonizers.

Whereas the use of ornamental plants in patios represented a reproduction of European botanical practices, the interactions between people and plants maintained in nearby uncultivated ecosystems, such as páramos, evinced the prolonged relationship between native American descendants and wild plants. It can be argued that the high levels of poverty and social marginalization experienced by mestizos and native American descendants forced them to use their vernacular knowledge of native plants as a means of survival. This situation is exemplified by the extractive uses of NTFPs such as pajonal, chusque, totumos, and totora along with forest products such as charcoal and firewood generally undertaken by the poorest. Both socially and spatially marginalized, these people lived in so-called tiendas (small rented rooms) and lacked access to private spaces to enjoy gardens created by the manipulation of ornamental plants. Hence, their botanical interactions were circumscribed to native plants spontaneously growing in the urban periphery, or, in the best scenario, in solares where female servants had contact with medicinal herbs and edible plants.

The extended uses of plants or products made through the manipulation of plants (e.g., woven mats) in nineteenth-century Bogotá evidences the social importance of the vernacular botanical knowledge usually embodied in the poorest individuals of the city. In addition, Bogotás dependence on plants and NTFPs indicates that many daily needs in the pre-industrial city were at least partially solved due to the extensive botanical diversity of the Andes. Finally, the wide range of plants and NTFPs described by travelers who visited Bogotá in the nineteenth century indicates that the extensive exchanges and trade connections present in preColumbian Bogotá remained active during the Colonial and Early Republican periods (Langebaek 1987). However, more investigation is needed to understand continuities and disruptions in the use of plants and NTFPs in the city's history.

The findings of this study exemplify how ecological differences between social classes in contemporary urban societies are not a new phenomenon and highlight how the concept of "ecological gentrification" used in urban studies refers to historically produced social dynamics (Braswell 2018). In the particular case of nineteenth-century Bogotá, the socio-ecological differentiation between types of green spaces is illustrated by distinctions in the ways of understanding and using plants. Specifically, the results presented in this paper align with contemporary evidence showing that whereas medicinal and edible plants tend to be more prevalent among low-income families, ornamental plants are a feature of the gardens in middle-and upper-class houses (Sierra-Guerrero and Amarillo-Suárez 2017).

\section{The Ethnobotanical Consequences of the City's Modernization}

The types of green spaces present in Bogotá during the second half of the nineteenth century were remnants of colonial urbanism. The accelerated urbanization process that Bogotá underwent during the latter nineteenth century resulted in the rapid disappearance of green spaces such as patios and solares that had promoted particular uses of plants in the city. For instance, in an attempt to host a population in constant growth, many houses with patios were subdivided, and their resulting rooms, known as tiendas, were rented to needy families (Mejía 2000). This change in the domestic sphere around patios led to the abandonment of the gardens previously planted on patio surfaces. Soledad Acosta lamented the loss of private green spaces when she wrote that "Almost all the flowers loved by my godmother back in the days have lost their importance." Such statements highlight the disappearance of a very particular type of private 
urban garden that scholars have not yet fully explored.

Additionally, although the historical evidence concerning the floristic composition of these gardens is severely limited, it is highly probable that their disappearance entailed the loss of uncommon plants used in the decoration of these places, which still occurs in contemporary patios in Central American cities (González-García and Sal 2008).

The urbanization of Bogotá also implied the disappearance of the solares and their edible and medicinal plants. Indeed, the economic limitations that prevented the city's expansion engendered a concentration of people in the traditional quarters, and open spaces such as solares were rapidly urbanized (Mejía 2000). The disappearance of the solares expelled the last traces of the rural life that had coexisted with urban practices throughout Bogotás history. Nevertheless, although the urbanization of solares may have eradicated the cultivation of edible plants such as the "cubios," potatoes, or Andean papaya described by Isaac Holton (1857), it did not undermine the use of other plants such as medicinal herbs. Studies of present-day Bogotá have illuminated the "astonishing" uses of herbs in the city (Bussmann et al. 2018; Giraldo et al. 2019). Other recent works have reported that despite the lack of large solares, lower-income people have continued cultivating medicinal and aromatic herbs in pots and small domestic gardens (Sierra- Guerrero and Amarillo-Suárez 2017).

\section{Conclusion}

Colombia is home to the third most biodiverse flora of the world (Raven et al. 2020). However, the majority of the botanical studies aiming to explore the rich country's flora have ignored a) the historical dimension of this botanical diversity and b) the key role of plants in the development of Colombian cities. This research shows how Bogotá has been a scenario of particular social-related ethnobotanical knowledge and practices, and how they have been modified by historical transformations in the builtenvironments as a response of social, economic, and political changes. This research has sought to rethink the usually underestimated relationship between ethnobotanical and environmental history studies and help as an initial reference for further studies, which using more precise methods (e.g., phytolhits) could provide a broader outlook of the botanical universe of the pre-industrial Bogotá.
Also, this investigation can serve as a starting point in diachronic comparisons between green spaces, their flora, and their ethnobotanical practices existing in the past and those in the present today.

\section{Supplementary Information}

The online version contains supplementary material available at https://doi.org/10.1007/s12231021-09524-5.

\section{Acknowledgments}

I would like to thank Giuseppe Feola, Hilary Geoghegan, and Katherine Mora for their comments on an earlier version of this paper. I kindly thank anonymous referees for their valuable comments and suggestions, as well as the staff of the Archivo General de la Nación, the Biblioteca Pública Piloto, and the Kew Botanical Garden for their help and advice. Lastly, many thanks to the Fundacion de Amigos de Bogotá and to CharlesHenry Dubail and Association Ernest Bourgarel for their authorisation in the use of their images.

\section{Literature Cited}

Aceituno, F. and J. Martín. 2017. Plantas emeriandias en la mesa de los primeros europeos en Panamá viejo. Latin American Antiquity 28(1):127-143. https://doi.org/10.1017/laq. 2016.9.

Acevedo, J. 1869. Tratado sobre economia domestica para el uso de las madres de familia, de las amas de casa y de las escuelas de niñas. Bogotá: Imprenta de Gaitan. http://babel. banrepcultural.org/cdm/ref/collection/ p17054coll10/id/1727. (23 October 2020).

Acosta de Samper, S. (1870). 2013 Mi Madrina. In: Recuerdos de Santafé, eds., Antonio Garcia, 1732. Bogotá: Intituto Distrital de las ArtesIdartes.

Amigo, A. 2018. Identidad, modernidad, ocio: jardines urbanos de La Habana en el siglo XIX. Cuban Studies 46:87-112. https://doi.org/10. 1353/cub.2018.0006.

Anderson, E. 1969. Plants, man and life. Berkeley: University of California Press.

André, É. 1878. L’América Équinoxiale (ColombieÉquateur-Pérou). Le Tour Du Monde: Nouveau Journal Des Voyages, Vol. 35, 161-177.

Braswell, T. 2018. Fresh food, new faces: Community gardening as ecological gentrification in St. 
Louis, Missouri. Agriculture and Human Values 35(4): 809-822. https://doi.org/10.1007/ s10460-018-9875-3.

Bussmann, R. W., N. Y. Zambrana, C. Romero, and R. E. Hart. 2018. Astonishing diversity-The medicinal plant markets of Bogotá, Colombia. Journal of Ethnobiology and Ethnomedicine 14(1):43. https://doi.org/ 10.1186/s13002-018-0241-8.

Bye, R. and E. Linares. 2015. Perspectives on Ethnopharmacology in Mexico. In: Perspectives on Ethnopharmacology, eds., M. Heinrich and A. K. Jäger, 393-404. Chinchester: John Wiley \& Sons, Ltd. https://doi.org/10.1002/ 9781118930717.ch33.

Caballero, J. 1992. Maya homegardens: Past, present and future. Etnoecológica 1(1):35-54.

Calvachi, B. 2002. La diversidad Bogotana. Revista La Tadeo 67:89-98.

Capitel, A. 2005. La arquitectura del patio. Barcelona: Gustavo Gili.

Cook, I. and P. Crang. 1996. The world on a plate: Culinary culture, displacement and geographical knowledges. Journal of Material Culture 1(2): 131 - 153. https://doi.org/10.1177/ 135918359600100201.

Cordovez, J. 1899. Santafé y Bogotá, 3rd ed., Vol. 1. Bogotá: Librería Americana.

Cronon, W. 1992. Nature's metropolis: Chicago and the great west. New York: W. W. Norton \& Company.

Crosby, A. 1993. Ecological imperialism: The biological expansion of Europe, 900-1900. Cambridge: Cambridge University Press.

Díaz, E. (1880). 1985 Novelas y cuadros de costumbres-Bruna la carbonera, Vol. II. Bogotá: Procultura.

Dubail, C. and M. Dubai-Acero, eds. 2017. Bourgarel, le Colombien: Voyages d'un diplomate français dans la Colombie du XIXe siècle. Paris: EdiSens.

Evans, S. 2000. Aztec royal pleasure parks: Conspicuous consumption and elite status rivalry. Studies in the History of Gardens \& Designed Landscapes 20(3):206-228. https://doi.org/10. 1080/14601176.2000.10435621.

Fernández de Oviedo y Valdes G. 15261851. Historia general y natural de las Indias. Madrid: Impr. de la Real academia de la Historia, https:// archive.org/details/generalynatural01fernrich. (5 September 2020).

Fundación Amigos de Bogotá. 2010. Antigua Bogotá, 1880-1948. Bogotá: Editorial Planeta.
Giraldo, S., M. Bernal, R. Sánchez, and Y. Lozano. 2019. Ethnopharmacological studies in traditional markets from Bogotá D.C. (Colombia): Advances and perspectives for the search of medicinal plants with therapeutic potential. Farmajournal 4(1):253-254.

González-García, A. and A. Sal. 2008. Private urban greenspaces or "Patios" as a key element in the urban ecology of tropical Central America. Human Ecology 36(2):291-300.

Guerra, R. 1888. La Guadua. Papel Periódico Ilustrado, 26. Bogotá, Colombia.

Holton, I. 1857. New Granada. Twenty months in the Andes. New York: Harper \& Brothers.

Langebaek, C. 1987. Mercados, poblamiento e integración étnica entre los Muiscas siglo XVI. Bogotá: Banco de la República.

Lombana, J. and F. Ayala. 1887. Precios de los materiales de construcción en la ciudad de Bogotá. Anales de Ingeniería 1(1):32.

Martínez, A. 1996. La vida material en los espacios domésticos. In: Historia de la vida cotidiana en Colombia, eds., B. Castro, 337-362. Bogotá: Grupo Editorial Norma.

Mead, G. 1970. On the improper usage of common names when giving botanical data. American Antiquity 35(1):108-109. https://doi.org/10. 2307/278186.

Medeiros, M. and N. Hanazaki. 2009. Etnobotânica histórica: Princípios e procedimentos. Recife: NUPEEA.

Mejía, G. 2000. Los años del cambio. Historia urbana de Bogotá, 1820-1910, Segunda edición. Bogotá: Pontificia Universidad Javeriana.

Myers, N., R. Mittermeier, C. Mittermeier, G. da Fonseca, and J. Kent. 2000. Biodiversity hotspots for conservation priorities. Nature 403(6772): 853-858. https://doi.org/10.1038/35002501.

Molina, D. 2015. Los árboles se toman la ciudad. El proceso de modernización y la transformación del paisaje en Medellín, 1890-1950. Medellín: Editorial Universidad de Antioquia.

Morales, J. 2004. Jardines prehispánicos de México en las crónicas de Indias. Archivo Español de Arte 77(308):351-373.

Patiño, M. 1967. Plantas cultivadas y animales domésticos en América Equinoccial, Vol. III. Cali: Imprenta Departamental.

Paz, O. 1999. El laberinto de la soledad, Postdata y vuelta al laberinto de la soledad, 3ra ed. México: Fondo de Cultura Económica.

Pérez, F. 1862. Jeografia fisica i politica de los Estados Unidos de Colombia, Vol. I. Bogotá: 
Imprenta de la Nación. http://hdl.handle.net/ 2027/wu.89044216349. (7 May 2020).

Raven, P. H., R. E. Gereau, P. B. Phillipson, C. Chatelain, C. N. Jenkins, and C. U. Ulloa. 2020. The distribution of biodiversity richness in the tropics. Science Advances 6(37). https:// doi.org/10.1126/sciadv.abc6228.

Reyes, C. and J. González. 1996. La vida doméstica en la ciudades republicanas. In: Historia de la vida cotidiana en Colombia, ed., B. Castro, 205-240. Bogotá: Grupo Editorial Norma.

Romero, J. 2014. Latinoamérica las ciudades y las ideas. Buenos Aires: Siglo veintiuno.

Samper, M. 1898. La miseria en Bogotá. Bogotá: Universidad Nacional.

Sierra-Guerrero, M. and A. Amarillo-Suárez. 2017. Socioecological features of plant diversity in domestic gardens in the city of Bogotá, Colombia. Urban Forestry \& Urban Greening 28:54-62. https://doi.org/10.1016/j.ufug.2017.09.015.

Silva, M. 2001. La vivienda a patios de origen hispánico y su difusión en Iberoamérica. Sevilla Actas III, Congreso Internacional del barroco Americano: territorio, arte, espacio y sociedad 70. https://dialnet.unirioja.es/servlet/articulo? codigo $=4088197$. [ 27 November 2019)]

Silva, T. P. Medeiros, A. Balcázar, T. Araújo, A. Pirondo, and M. Medeiros. 2014. Historical ethnobotany: An overview of selected studies.
Ethnobiology and Conservation 3(4):1-12. https://doi.org/10.15451/ec2014-6-3.4-1-12.

Sociedad de Mejoras y Ornato. 1938. Bogotá, 1538-1938. Con motivo del cuarto centenario de la fundación de la ciudad. Sociedad de Mejoras y Ornato. Bogotá: Sociedad de Mejoras y Ornato.

Stark, B. 2014. Ancient open space, gardens, and parks: A comparative discussion of Mesoamerican urbanism. In: Making ancient cities. Space in early urban societies, eds., A. Creekmore III and K. Fisher, 370-406. Cambridge.: Cambridge University Press.

Steuart, J. 1838. Bogota in 1836-7: Being a narrative of an expedition to the capital of the NewGranada and a residence there of eleven months. New York: Harper \& Brothers.

Van der Hammen, T. 2003. La estratigrafía e historia del Neogeno y cuaternario de la cuenca alta del río Bogotá. Análisis Geográficos (IGAC) 26:101-120.

Wylie, L. 2018. Floriography, sexuality and the horticulture of hair in Jorge Isaacs' María. Bulletin of Spanish Studies 95(9-10):147-158. https://doi.org/10.1080/14753820.2018. 1547000.

Zambrano, F. 2007. Historia de Bogotá. Siglo XX, Vol. III, 2nd ed. Bogotá: Villegas Editores. 